Biol. Stud. 2016: 10(3-4); 107-118 • DOI: https://doi.org/10.30970/sbi.1003.497

www.http://publications.Inu.edu.ua/journals/index.php/biology

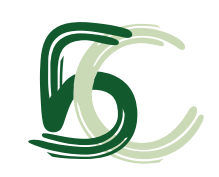

UDC 581.192: 581.142: 631.811 .98

\title{
EFFECTS OF SEED PRIMING WITH GROWTH REGULATOR BIOLAN ON SALT TOLERANCE OF PISUM SATIVUM L.
}

\author{
M. V. Dmytruk, N. V. Vasyliv, I. V. Derkach, I. M. Mykiyevych, N. D. Romanyuk* \\ Ivan Franko National University of Lviv, 4, Hrushevskyy St., Lviv 79005, Ukraine \\ *e-mail: biofr@franko.Inu.edu
}

Growth regulator Biolan (“Agrobiotech”, Kyiv) positively influenced physiological and biochemical responses of Pisum sativum L. (var. Alpha) in laboratory experiments, carried out in the presence of 0 (control), 2 and $4 \% \mathrm{NaCl}$. NaCl delayed the time-course of water uptake by germinating seeds, growth and emergence of an embryonic axes, inhibited germination activity, plants early growth (fresh and dry matter accumulation), chlorophyll $a$, chlorophyll $b$ and carotenoids contents. $\mathrm{Na}^{+}, \mathrm{Ca}^{2+}$ and $\mathrm{K}^{+}$homeostasis under the $2 \% \mathrm{NaCl}$ impact disturbed, $\mathrm{Ca}$ content and $\mathrm{K} / \mathrm{Na}$ ratio dramatically decreased. Biolan applied for seeds priming in dilution $1: 10^{5}(6 \mathrm{~h})$, promoted water uptake by seeds and germination, it increaced $\mathrm{Chl} a / b$ ratio in leaves either with or without $\mathrm{NaCl}$. Seed priming with Biolan lead to partial restoring $\mathrm{K} / \mathrm{Na}$ ratio and slight alleviation the total salt inhibitory effects; it seems to be a reliable approach to increase salt tolerance in a field conditions.

Keywords: Pisum sativum L., plant growth regulator, seeds priming, Biolan, $\mathrm{NaCl}$, salt tolerance.

\section{INTRODUCTION}

High yields of major agricultural crops and their resistance to adverse environmental factors, including soil salinization, are one of the priority tasks of plant biology. Salinization gradually decrease yields, affecting seed germination, photosynthesis, changing "the mobilization of stored reserves and affecting the structural organization of proteins" [17; 20]. The practical importance of studies on salt tolerance increases with the increasing areas of saline soils [20]. In Ukraine large areas with high salt levels are primarily located in the southern and central parts of Ukraine and on all irrigated lands [7, 42, 43, 61]. Different approaches to improve physiological processes and enhance crop yield under salt environment are tested, among them is seed priming with plant growth regulators (PGR), for example ivin, kinetin, 6-BAP, fusicoccin, ethylen, salicylic acid, methyljasmonate, etc $[11,17,24,25,28,31,41,47]$. This process makes a seed and seedling more resistant to salt exposure due to changing metabolism, including free radical scavenging activity, membranes repair and influencing transport activity [13]. Finally it increases seed vigor and emergence under the salt impact; promote formation of strong root system etc. However, PGR priming effects differ for different species and varieties, depend 
on the concentration, developmental phase, mineral nutrients availability, climatic environment etc [8, 44, 45]. Application of PGR Biolan ("Agrobiotech", Kyiv) reported as an effective way to manage plants ontogenesis, tolerance to the impact of stress factors and contribute to the complete realization of genetic potential $[45,63]$. It consists of low toxic, balanced composition of phytohormones, amino acids, fatty acids, oligosaccharides, chitosan and mineral elements ( $\mathrm{Zn}, \mathrm{Cu}, \mathrm{Mn}, \mathrm{Mg}, \mathrm{Ca}, \mathrm{Fe}, \mathrm{Na}, \mathrm{K})$ in biogenic form; promotes cells division, root system development, an increase of total leaves area and chlorophyll content; decrease phytotoxic effects of pesticides, heavy metals, improves quality production and increase yield [8,44]. Taking into account existing literature data it was assumed that Biolan would improve salt tolerance of pea (Pisum sativum L.) which is regarded as useful model species in plant biology, characterized as moderate salt-tolerant species [10] and is an important food resource for people and animals [21, $29,30,39,62]$. It improves soil structure and fertility, is good source for $\mathrm{P}, \mathrm{K}, \mathrm{Ca}$ and widely used as culture for crop rotation. In many cases pea is grown on soils where growth and yield are limited by salinity. Although the effects of salinity on growth, nodulation, $\mathrm{N}_{2}$ fixation, photosynthetic pigments content of this species has been widely studied $[21,30,32,50,62]$, there is no data on the salt tolerance of this culture under the seeds priming with PGR Biolan. Thus, this study assessed the Biolan influence on salt responses of $P$. sativum L. (var. Alpha) in controlled laboratory experiment.

\section{MATERIALS AND METHODS}

Seeds pre-treatment. Pea seeds ( $P$. sativum, var. Alpha) were used as experimental material. Calibrated by size seeds were sterilized and divided into two groups. One group of seeds was pre-soaked for 6 hours in a water solution of the Biolan, dilution of $1: 10^{5}$, another group (control) was pre-soaked in distilled water.

Germinating seeds. The dynamics of seed germination was studied by the rate of imbibitional water uptake and elongation of embryonic axis [12]. For this matter 50 presoaked seeds were weighed and placed on the moist filter paper in each Petri dish $(10 \mathrm{~cm})$ at 0 and $2 \%$ sodium chloride concentrations in a dark thermostat at $20 \pm 1{ }^{\circ} \mathrm{C}$. After 6 hours, 12, 24, 48 and 72 hours, germinating seeds from each Petri dish were removed, weighed and returned back to the dishes (excess of moisture was taken away with dry filter paper). The water absorbed was calculated in mg by difference between weight of swallen and dry seeds. Germination energy and germination percentage were calculated [45].

Growing plants 3-days-old seedlings were were transferred in plastic pots, containing equal quantities of soil with added $\mathrm{NaCl}(0,2$ and $4 \%), 15 \mathrm{~cm}$ in diameter and $20 \mathrm{~cm}$ height. The seedlings were grown in the greenhouse under natural lighting, $(20 / 14) \pm 2{ }^{\circ} \mathrm{C}$ (day/night). The pots were distributed randomly. Pots were irrigated every three days. After 5 days number of plants per pot was decreased to 10, and only homogenous seedlings showing the strongest growth, were selected. Specimens were collected on the $21^{\text {st }}$ day from the treatment. The total age of the plants at that time was 24 days.

Growth measurements. Growth measurements for the plants exposed to the salt included measurement of fresh and dry weights of the 24-days plants as described [15].

For determination of photosynthetic pigments content $500 \mathrm{mg}$ of plant leaves were homogenized in $80 \%$ acetone, with the addition of the small amount of $\mathrm{CaCO}_{3}$. Chlorophylls and carotenoids content was measured colorimetrically at $663 \mathrm{~nm}, 645$ and $470 \mathrm{~nm}$ as described [37].

ISSN 1996-4536 (print) • ISSN 2311-0783 (on-line) • Біологічні Студії / Studia Biologica • 2016 • Том 10/№3-4 • С. 107-118 
Potassium, sodium, calcium in plant material was determined by flame photometry method with flame photometer ПФМ-БП-3О МЗ [19].

Statistical analysis. A total of three replicates were chosen for each measurement (at an average of three plants per replica). The results were statistically analyzed, $M \pm m$ determined using Microsoft Excel data analysis package. Levels of significant differences between groups were determined by the Student's $t$-test. $P$ values less than 0.05 were considered statistically significant.

\section{RESULTS AND DISCUSSION}

Biolan impact on pea seed germination under the salt environment. The initial stages of growth and development of peas are more sensitive to salinity [27]. Seed priming with PGR has been efficient for increasing seed vigor and seedlings growth under stressful environment (Fig. 1). In control variant without Biolan and salt treatment, germination energy (GE) of pea seeds achieved $67 \%$, germination percentage (GP) $85 \%$. In variant with seeds pre-treatment with PGR Biolan $\left(1: 10^{5}\right)$ promotion of early seed germination rates for $10 \%$ was observed. It has practical importance, since seeds of high vigor have high level of germination in the field conditions. Generally salt reduces the GP, due mainly to osmotic stress and toxic ions $\mathrm{Na}^{+}$and $\mathrm{Cl}^{-}[5,49,58$, ]. Excess of these ions enhance the osmotic potential of the soil solution and restrict water up-take by seeds and plants. Indeed, in our experiments salt stress caused substantial inhibition of seed germination, whereas Biolan treatment led stimulation of this process (Fig. 1). Finally the GP on the $5^{\text {th }}$ day of germination in variant with $2 \% \mathrm{NaCl}$ and Biolan treatment achieved $40 \%$, as opposed to $30 \%$ for untreated ones. Under severe salt stress $(4 \% \mathrm{NaCl})$ only $7 \%$ of seeds germinated, Biolan priming resulted in germination of $11 \%$ seeds. Therefore, further experiment was performed with only $2 \% \mathrm{NaCl}$.

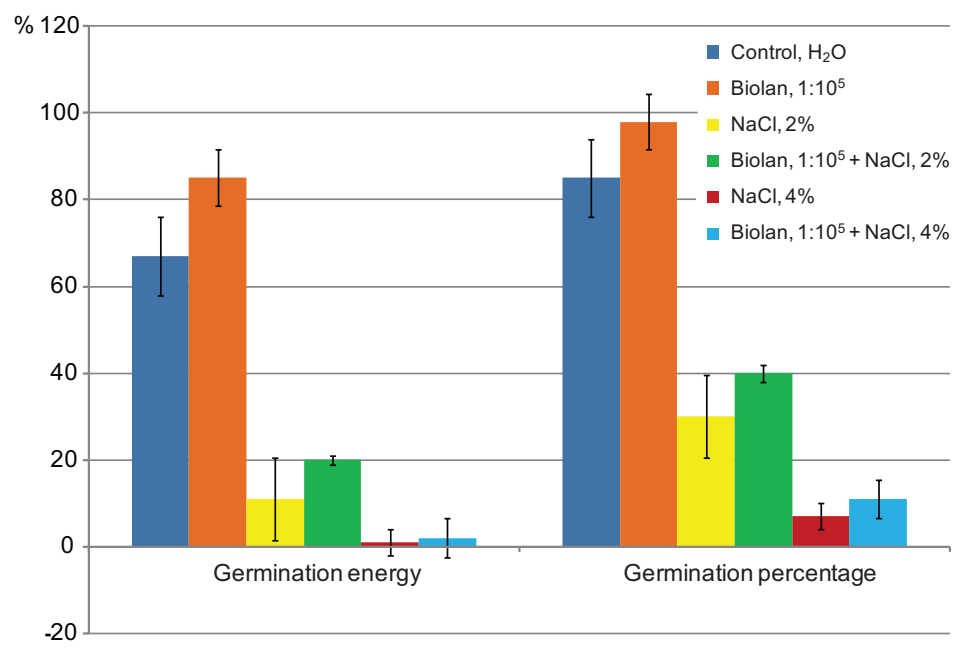

Fig. 1. Germination energy and germination percentage (\%) of pea seeds (var.) Alpha under the $\mathrm{NaCl}$ and Biolan influence (seeds priming, $1: 10^{5}$ water solution), Petri dishes, $t=20 \pm 1{ }^{\circ} \mathrm{C}$. Control - seeds presoaked in the distilled water. Values are means of three replicates with three plants per replicate. $P<0.05$

Рис. 1. Енергія проростання та схожість насіння (\%) гороху сорту Альфа за дії $\mathrm{NaCl}$ і препарату Біолан (попереднє замочування, $1: 10^{5}$ ), чашки Петрі, $\mathrm{t}=20 \pm 1^{\circ} \mathrm{C}$. Контроль - насіння, попередньо замочене у дистильованій воді

ISSN 1996-4536 (print) • ISSN 2311-0783 (on-line) • Біологічні Студії / Studia Biologica • 2016 • Том 10/№3-4 • C. 107-118 
The changes of germination rates obviously associated with the rate of seeds imbibition and growth of embryonic axes. Thus, we analyzed the water uptake during germination under $2 \% \mathrm{NaCl}$ and Biolan impacts. Water uptake time-course studies of $P$. sativum (Fig. 2), is reflected by changes in fresh weight. Seeds imbibition was already noticed on 6th hour of experiment, and for the $72^{\text {th }}$ hour the maximum water uptake was observed. It was revealed that Biolan pre-treatment partially eliminated negative salt effect, but it was substantially lower than in control $(0 \mathrm{NaCl})$. Inhibition of germination by salt resulted from osmotic effect rather than $\mathrm{NaCl}$ toxicity [18]. Seed priming promoted the pre-germination processes and maked the seed ready to germinate, besides, it could develop "different defence mechanisms against salt stress" [17]. There are reports on positive effect of hydropriming on germination processes under salt stress [28]. The use of primed seeds is suggested, as Biolan is more helpful in overcoming the negative effect imposed by reduced water potential upon seed germination.

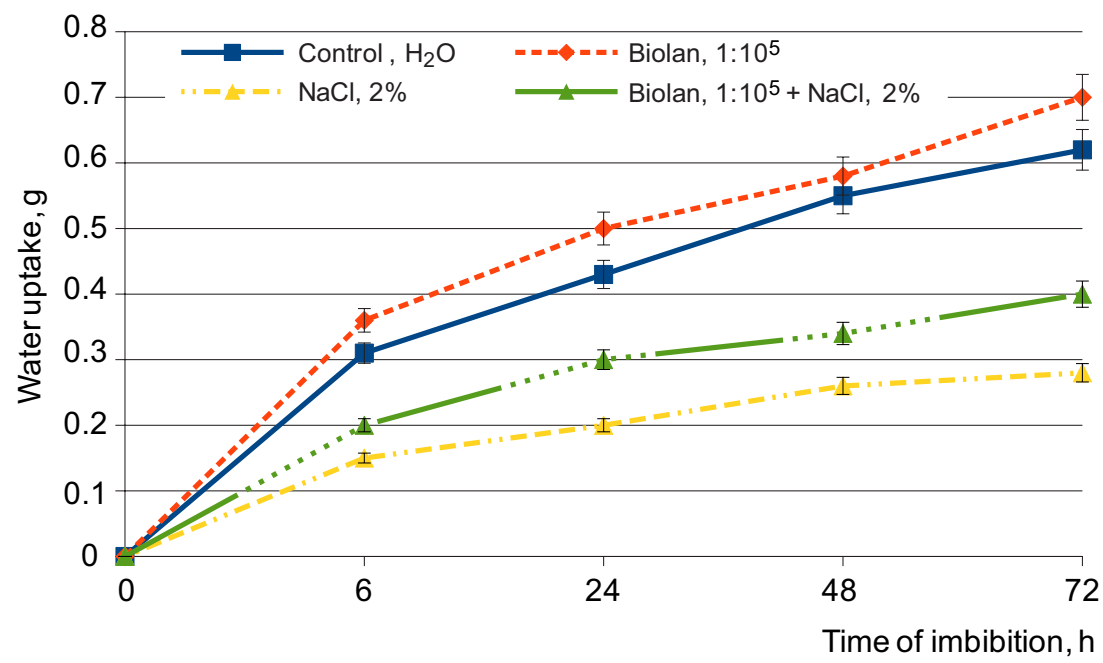

Fig. 2. Time dependence of water uptake by germinating pea seeds (var. Alpha), Petri dishes, $20 \pm 1{ }^{\circ} \mathrm{C}$, Biolan priming $\left(1: 10^{5}\right.$ solution, $\left.6 \mathrm{~h}\right)$ and $\mathrm{NaCl}(2 \%)$ impact. Values are means of three replicates with three plants per replicate. $P<0.05$

Рис. 2. Часова залежність поглинання води насінням гороху сорту Альфа при проростанні за передобробки насіння препаратом Біолан (замочування у розчині $1: 10^{5}, 6$ год) і $\mathrm{NaCl}(2 \%)$ засолення чашки Петрі, $20 \pm 1^{\circ} \mathrm{C} . P<0,05$

Influence of Biolan on early growth of $\boldsymbol{P}$. sativum plants. Pea plants obtained from seeds primed with Biolan and after germination grown on a soil during next 21 days had increased fresh and dry weights parameters (Tab. 1). Plants were looking stronger, total leaf area was higher. The fresh weight of aboveground parts exceeded control for 52 and $138 \%$ (leaves and stems), dry weight - for 17 and $90 \%$, respectively. The root system of plants under Biolan impact was more extensive, with numerous lateral roots (Fig. 3). However, the root length in control was larger twice, the fresh weight exceeded control by $103 \%$ and the difference between the dry weights was equal $45 \%$.

ISSN 1996-4536 (print) • ISSN 2311-0783 (on-line) • Біологічні Студії / Studia Biologica • 2016 • Том 10/№3-4 • C. 107-118 

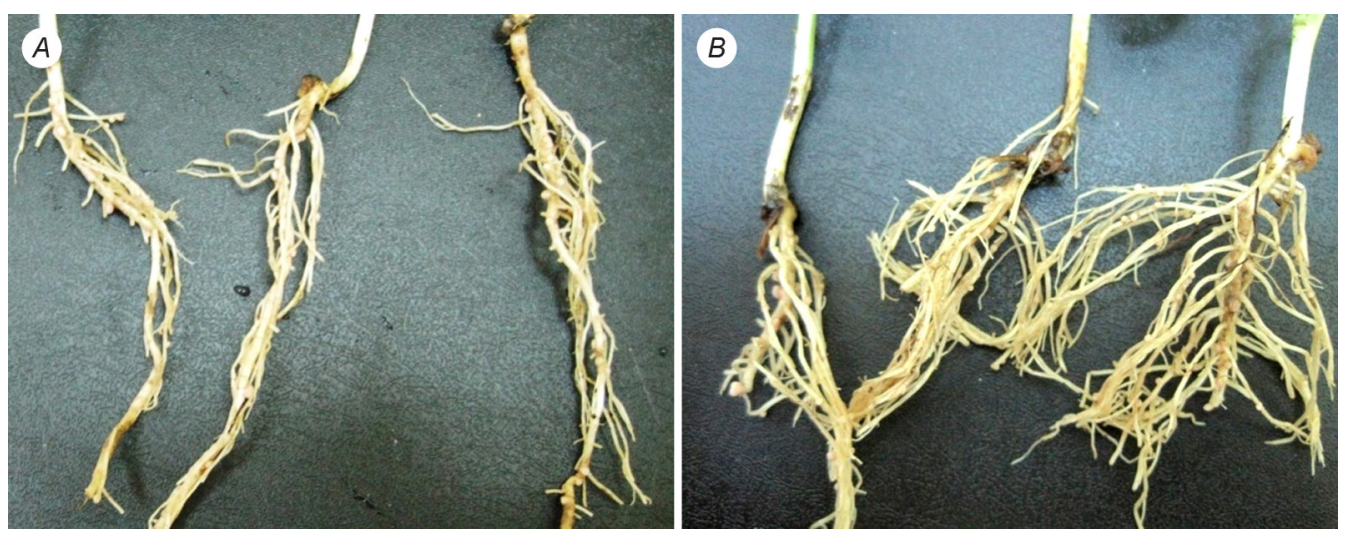

Fig. 3. Roots of 24-days pea plants (var. Alpha) grown in soil culture. $A$-control, seeds pre-sowed in distilled water; $B$ - seeds primed with PGR Biolan $\left(1: 10^{5}, 6 \mathrm{~h}\right)$

Рис. 3. Загальний вигляд коренів 24-добових рослин гороху (сорт Альфа), вирощених в умовах ґрунтової культури. $A$ - контроль, насіння попередньо замочене у воді; $B$ - передобробка регулятором росту Біолан $\left(1: 10^{5}, 6\right.$ год)

Table 1. Effects of seed priming with PGR Biolan $\left(1: 10^{5}\right)$ on accumulation of fresh (FW) and dry weight (DW) different organs of pea (var. Alpha) plants under $\mathrm{NaCl}$ salinity, soil culture, $21^{\text {th }}$ day of exposition. Control plants grown from seeds presowed in distilled water

Таблиця 1. Вплив допосівної обробки насіння препаратом Біолан $\left(1: 10^{5}\right)$ на нагромадження маси сирої (FW) та сухої речовини (DW) у різних органах гороху сорту Альфа, за умови $\mathrm{NaCl}$ засолення, ґрунтова культура, 21-ша доба експозиції. Контроль - рослини, вирощені з насіння, замоченого у воді

\begin{tabular}{|l|c|c|c|c|c|c|}
\hline \multirow{2}{*}{ Variant } & \multicolumn{2}{c|}{ Leaves } & \multicolumn{2}{c}{ Stem } & \multicolumn{2}{c}{ Roots } \\
\cline { 2 - 7 } & FW, mg & DW, mg & FW, mg & DW, mg & FW, mg & DW, mg \\
\hline Control, $\mathrm{H}_{2} \mathrm{O}$ & $542.2^{ \pm 42.8}$ & $50.2^{ \pm 4.5}$ & $363.1^{ \pm .24 .9}$ & $50.0^{ \pm 1.9}$ & $410.0^{ \pm 70.7}$ & $26.5^{ \pm 1.7}$ \\
\hline Biolan $1: 10^{5}$ & $828.0^{ \pm 70.1}$ & $58.8^{ \pm 2.3}$ & $866.2^{ \pm 40.5}$ & $95.0^{ \pm 1.1}$ & $830.0^{ \pm 60.7}$ & $38.8^{ \pm 2.6}$ \\
\hline $\mathrm{NaCl}, 2 \%$ & $257.4^{ \pm 31.3}$ & $34.1^{ \pm 4.3}$ & $160^{ \pm 28.3}$ & $40.1^{ \pm 8.3}$ & $240.0^{ \pm 30.3}$ & $28^{ \pm 3.4}$ \\
$\mathrm{NaCl}, 4 \%$ & - & - & - & - & - & - \\
\hline Biolan $+\mathrm{NaCl}, 2 \%$ & $472.0^{ \pm 30.3}$ & $44.3^{ \pm 3.4}$ & $377.5^{ \pm 50.4}$ & $46.3^{ \pm 2.8}$ & $352.5^{ \pm 50.7}$ & $27.5^{ \pm 2.1}$ \\
\hline Eiolan $+\mathrm{NaCl}, 4 \%$ & $328.7^{ \pm 30.3}$ & $26.3 \pm 1.3$ & $216.3^{ \pm 30.5}$ & $41.3^{ \pm 2.7}$ & $187.5^{ \pm 60.8}$ & $17.5^{ \pm 2.4}$
\end{tabular}

Under the $\mathrm{NaCl}$ impact the reduction of pea plants biomass was indicative of several growth limitations, where root growth was more sensitive. The $4 \% \mathrm{NaCl}$ treatment caused symptoms of phytotoxicity - the leaves became brown, yellow and dry; the root tips turned brown. Finally plants grown on the soil substrate with $2 \% \mathrm{NaCl}$ died. In spite of the fact that many studies revealed stimulative effect of $\mathrm{NaCl}$ on fresh and dry matter accumulation, there are contrary results pointing to the inhibitory effects, mainly it depends on salt concentrations used in experiments [9, 22, 57]. The beneficial effects of Biolan seed-priming were evident on plant growth at both studied $\mathrm{NaCl}$ concentra-tions. In variant $4 \% \mathrm{NaCl}$ with seeds pre-treatment, plants, despite the significant growth inhi- 
bition, remained viable. Fresh weight of leaves achieved $61 \%$ to control, dry weight $50 \%$ to control. In variant with $2 \% \mathrm{NaCl}+$ Biolan it was 87 and $88 \%$ to control, respectively for fresh and dry weight. So, we can assert the existence of a positive improving salt tolerance effect of seed priming with PGR Biolan $\left(1: 10^{5}\right)$ for pea. As a result of the seed priming with PGRs promotion of germination in the field conditions are reported by other researchers. Merkushyna et al. indicated that gibberellins treatment of pea seeds led to seed germination increment for $15.9 \%$ [35]. The fresh weight of roots increased to $57 \%$ due to the larger number of additional roots. According to $\mathrm{L}$. Anishyn under the Emistym $\mathrm{C}$ and Agrostymulin influence a total seed germination percentage of winter wheat increased by $4-6 \%$, and seeds vigor from 78 to $90-96 \%$ [3]. S.A. Shevchenko and S.P. Ponomarenko demonstrated that priming of winter wheat seeds with the biostimulants resulted in higher laboratory GP and higher absolute weight of seedlings [54] as well a more extensive root system [45].

The noticed decrease in the biomass due to $\mathrm{NaCl}$ treatment could be due to the negative effect of the photosynthesis, changes in enzyme activity and protein synthesis, and also a decrease in the level of carbohydrates and phytohormones, both of which can lead to inhibition of the growth [32]. Obviously Biolan could induce changes in all listed processes and parameters.

Effect of $\mathrm{NaCl}$ and Biolan on chemical content of $P$. sativum plants. Salinity reduces the ability of plants to utilize water, causes a reduction in growth rate, and cause changes in plant metabolism, especially photosynthesis [36, 37, 54]. The results of several published studies $[56,59]$ indicate that salinity reduces the content of photosynthetic pigments. Than growth inhibition occurs since the photosynthesis couldn't provide carbohydrate resources for newly emerging organs.

Photosynthetic pigments. Salt stress caused yellowing leaves and significant damage to chlorophyll pigments. Fig. 4 demonstrates the effect of $2 \% \mathrm{NaCl}$ on the level of chlorophylls and carotenoids in the leaves of pea plants. Under salt impact content of chlorophyll 'a' decreased, reaching its lowest level compared to control plants. The Biolant treatment on chlorophyll ' $a$ ', chlorophyll ' $b$ ' and carotenoids under salinity is also shown in Fig. 4. Total concentration of chlorophyll ' $a$ ' and ' $b$ ', carotenoids in the plants treated with Biolan was higher than in the untreated control. On other hand pea plants grown from seeds pre-treated with Biolan had a higher ratio of $\mathrm{Chl}$ ' $a$ ' / $\mathrm{Chl}$ ' $b$ ', than control plants. This ratio mainly characterizes the size of light harvesting complex II ( $\mathrm{LHClI})$, the main area of chl ' $b$ ' localization; it indicates adaptation of the photosynthetic apparatus to low light intensity and increasing the size of the antenna complex [15]. Thus, cells with small photosystem II have a higher ratio of Chl 'a' / Chl ' $b$ ', than cells with large well-developed LHC II. Total chlorophyll level in both (with and without Biolan) variants of salt-affected plants declined. Carotenoids decreased to a lesser extent than chlorophylls, significant differences for this parameter disappeared. For other legumes have been reported similar results [41, 51]. Like in work Amuthavalli and Sivasankaramoorthy on the pigeon pea [2], Chl 'a' was less sensitive or better protected against salt stress than Chl 'b'. In general changes in the chlorophylls content may be attributed to the increased degradation and/or inhibited synthesis [2, 34]. Our results agree with data Tort and Turkyilmaz [59] for the barley, Turan [60] for beans, Taffouo [56] for vigna. There are contradictionary data on carotenoids content under the salt stress [60].

ISSN 1996-4536 (print) • ISSN 2311-0783 (on-line) • Біологічні Студії / Studia Biologica • 2016 • Том 10/№3-4 • С. 107-118 


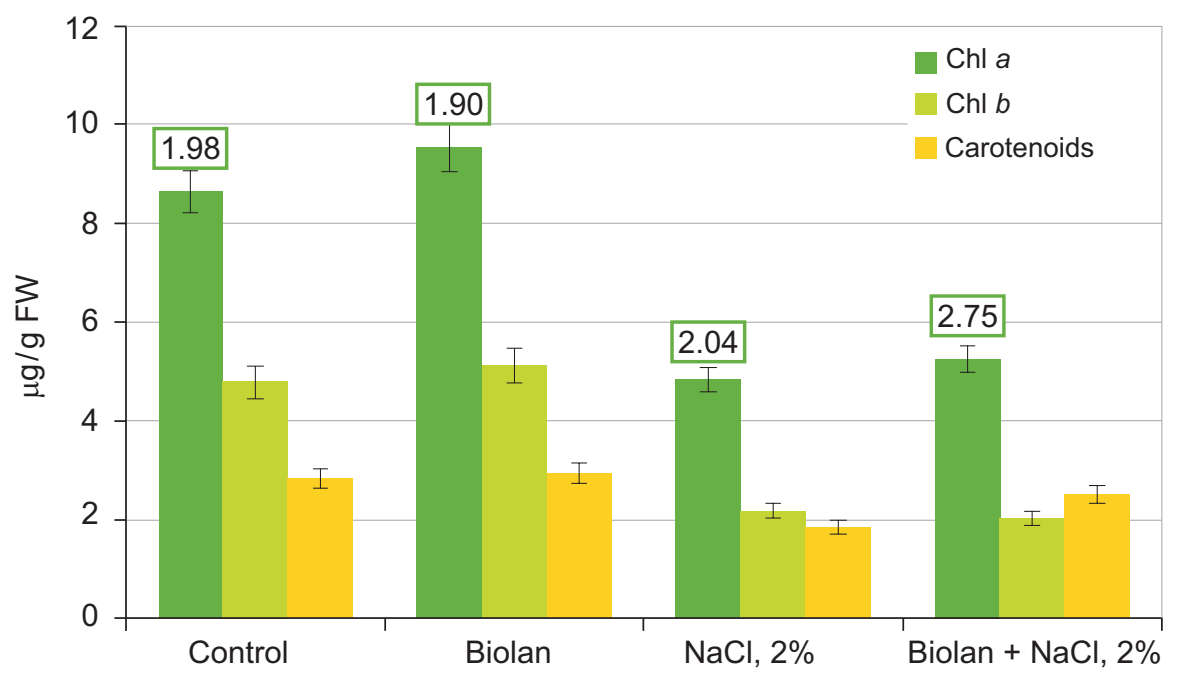

Fig. 4. Effect of seed priming with $P G R$ Biolan $\left(1: 10^{5}, 6 \mathrm{~h}\right)$ on photosynthetic pigments content in the $P$. sativum (var. Alpha) plants under the $2 \% \mathrm{NaCl}$ impact. Numbers in the box - the ratio Chl a / Chl $b$. 21 days of treatment, soil culture. Control - seeds pre-soaked in distilled water

Рис. 4. Вплив передобробки насіння Біоланом $\left(1: 10^{5}, 6\right.$ год) на вміст фотосинтетичних пігментів у листках P. sativum (сорт Альфа) за дії 2\% NaCl. 21-ша доба експозиції, ґрунтова культура. Цифрами у рамці позначено співвідношення Хл а / Хл $b$. Контроль - насіння, попередньо замочене у дистильованій воді

$\mathrm{Ca}, \mathrm{Na}$ and $\mathrm{K}$ content. Salinity stress disturbs the essential mineral elements uptake and accumulation [51-53]. One of the salt tolerance indices is accumulation of specific ions in plant tissues, whole-plant concentrations of $\mathrm{Na}, \mathrm{K}, \mathrm{Ca}$ are significantly correlated with yield and biomass production $[43,57]$. The entry of $\mathrm{Na}^{+}$into the plant cell is a passive process: a negative electrical potential difference at the plasma membrane and low cytosolic $\mathrm{Na}^{+}$strongly favor the movement of $\mathrm{Na}^{+}$into the cell. In contrast, $\mathrm{Na}^{+}$ extrusion and compartmentalization are, although indirectly, active processes. $\mathrm{Na}^{+} / \mathrm{H}^{+}$ antiporters mediate the compartmentalization of $\mathrm{Na}^{+}$within the vacuole and the extrusion of $\mathrm{Na}^{+}$from the cell $[14,23,37,48]$. These are two key processes in the concerned action of cytosolic $\mathrm{Na}^{+}$detoxification and cellular osmotic adjustment that are necessary to tolerate salinity stress. Under the high concentration of salt $\mathrm{Na}^{+}$and $\mathrm{Cl}^{-}$exclusion mechanisms are usually diminished and salt tolerance is strongly related to the osmotic potential of leaves, what was demonstrated for $V$. faba plants [57]. Obviously, under the influence of $\mathrm{NaCl}$ plants vary by the content of $\mathrm{K}^{+}, \mathrm{Na}^{+}, \mathrm{Ca}^{2+}$ ions. We determined the content of these elements in the ash of plants (Tab. 2). Biolan alone leads to increasing $\mathrm{Ca}$ content, the $\mathrm{K}$ and $\mathrm{Na}$ levels remained unchanged. Generally $\mathrm{Ca}^{2+}$ and $\mathrm{K}^{+}$decrease in plants under saline environment [53]. In our experiments salinity treatment significantly increased $\mathrm{Na}$ concentration of plants, $\mathrm{Ca}$ and $\mathrm{K}$ levels also decreased (63 and $40 \%$ to control). These decreases could be due to the antagonism of $\mathrm{Na}^{+}$and $\mathrm{K}^{+}$at uptake processes $[23,48,53]$. Recent studies in plant biology revealed that the high $\mathrm{K}^{+} / \mathrm{Na}^{+}$ ratio is crucial for salt resistance $[51,53]$. 
Table 2. Effects of $\mathrm{NaCl}(2 \%)$ and PGR Biolan (seed priming with 1:10 5 water solution) on whole-plant concentrations of calcium $(\mathrm{Ca})$, sodium $(\mathrm{Na})$, potassium $(\mathrm{K})$ and $\mathrm{K} / \mathrm{Na}$ ratio in pea (var. Alpha) plants, soil culture, $21^{\text {th }}$ day of salt exposition

Таблиця 2. Вплив $\mathrm{NaCl}(2 \%)$ і регулятора росту Біолан (замочування насіння, 1:105) на вміст кальцію (Ca), калію (K), натрію ( $\mathrm{Na}$ ) і співвідношення $\mathrm{K} / \mathrm{Na}$ у рослинах гороху (сорт Альфа). Ґрунтова культура, 21-ша доба росту в умовах засолення

\begin{tabular}{|l|c|c|c|c|c|c|c|}
\hline \multicolumn{1}{|c|}{ Variant } & \multicolumn{7}{c}{ Content of elements, ppm } \\
& $\mathrm{Ca}$ & $\%$ & $\mathrm{~K}$ & $\%$ & $\mathrm{Na}$ & $\%$ & $\mathrm{~K} / \mathrm{Na}$ \\
\hline Control, $\mathrm{H}_{2} \mathrm{O}$ & $1.56^{ \pm 0.01}$ & 100 & $7.53^{ \pm 0.15}$ & 100 & $0.94^{ \pm 0.10}$ & 100 & 8.01 \\
\hline Biolan, $1: 10^{5}$ & $1.94^{ \pm 0.01}$ & 124 & $7.07^{ \pm 0.09}$ & 94 & $1.10^{ \pm 0.11}$ & 117 & 6.42 \\
$\mathrm{NaCl}, 2 \%$ & $0.98^{ \pm 0.02}$ & 63 & $3.01^{ \pm 0.11}$ & 40 & $3.79^{ \pm 0.26}$ & 403 & 0.80 \\
\hline Biolan $1: 10^{5}+\mathrm{NaCl}, 2 \%$ & $1.41^{ \pm 0.01}$ & 91 & $4.07^{ \pm 0.33}$ & 54 & $2.65^{ \pm 0.22}$ & 281 & 1.54
\end{tabular}

Plants maintain high levels of $\mathrm{K}^{+}$and low content of $\mathrm{Na}^{+}$in the cytosol by regulating the expression and activity of $\mathrm{K}^{+}$and $\mathrm{Na}^{+}$transporters and $\mathrm{H}^{+}$pumps that provide energy for these transport processes [26, 47, 51, 65, 64]. Salt tolerance also depends on ability to keep apart $\mathrm{Na}^{+}$in subcellular compartments and/or maintain $\mathrm{K}^{+}$homeostasis stress. Accordingly, the increase in potassium and decrease in sodium content in the pea tissues under Biolan influence determines its protective effect in terms of salinity. Since salinity tolerance depends on expression of many salt tolerance genes we assume that seed priming with Biolan

\section{CONCLUSION}

Pea seeds (var. Alpha) priming with growth regulator Biolan promotes processes of seeds imbibition and its subsequent germination, which expressed in the rapid growth of the embryonic axes and high energy of germination (vigor). The optimum concentration that ensures maximum stimulating effect is volumetric dilution of $1: 10^{5}$, the duration of treatment -6 hours. $\mathrm{NaCl} 2$ and $4 \%$ caused reduction in the growth of pea. Results obtained indicated that the difference in growth at the salinity treatments can be attribute differences in ion accumulation and content of photosynthetic pigments, chlorophylls and carotenoids. Salinity treatment increased $\mathrm{Na}$ content and decreased $\mathrm{K}$ and Ca contents in plants tissues. PGR Biolan application in this study had positive effect on increasing chlorophylls level, decreasing of $\mathrm{Na}$ and increasing of $\mathrm{K}$ contents in the tissues of pea plants, and finally dry matter accumulation in soil culture.

1. Amira M.S., Qados A. Effect of salt stress on plant growth and metabolism of bean plant Vicia faba (L.) J. of the Saudi Soc. of Agricult. Sci, 2011; 10(1): 7-15.

2. Amuthavalli $P$, Sivasankaramoorthy S. Effect of Salt Stress on the Growth and Photosynthetic Pigments of Pigeon Pea (Cajanus Cajan). J. App. Pharm. Sci, 2012; 2(10): 131-133.

3. Anishyn L. A. Effect of bio-stimulators on yield and quality of winter wheat. Novyny Zahystu Roslyn, 1999; 7: 29-30. (In Ukrainian).

4. Ashraf M., Harris P.J.C. Potential biochemical indicators of salinity tolerance in plants. Plant Science, 2004; 166(1): 3-16.

5. Ashraf M.A., Ashraf M. Salt-induced variation in some potential physiological attribute of two genetically diverse spring wheat (Triticum aestivum L.) cultivars: photosynthesis and photosystem II efficiency. Pakistan Journal of Botany, 2012; 44: 53-64.

ISSN 1996-4536 (print) • ISSN 2311-0783 (on-line) • Біологічні Студії / Studia Biologica • 2016 • Том 10/№3-4 • C. 107-118 
6. Barber K.E. History of vegetation. In: Chapman S.B. (Ed.) Methods in Plant Ecology. Oxf.: Blackwell Sci. Publ., 1976: 5-83.

7. Bilyk G.I. Flora of salinized soils of Ukraine, development, usage and improvement. Kyiv: UAS, 1963. 300 p. (In Ukrainian).

8. Biologically active substances in plant production (Ed.) Grytsayenko Z.M., Ponomarenko S.P., Karpenko V.P. et al. Kyiv: Nichlava, 2008. 352 p. (In Ukrainian).

9. Bohnert H.J., Nelson D.E. Yensen R.G. Adaptations to environmental stress. Plant Cell, 1995; 7: 1099-1111.

10. Box E.O. Plant functional types and climate at the Global Scale. J. Veg. Sci, 1996; 7: 309320.

11. Carvalho R. F., Piottol F.A., SchmidtI D. Seed priming with hormones does not alleviate induced oxidative stress in maize seedlings subjected to salt stress. Sci. Agric. (Braz.), 2011; 68(5): 598-602.

12. Chakraborty R., Kar R.K. Differential water uptake kinetics in axes and cotyledons during seed germination of Vigna radiata under chilling temperature and cycloheximide treatment. Braz. J. Plant Physiol, 2008; 20(4): 277-284.

13. Chizhykova O.A., Palladiana T.O. Activity of key enzymes of proline synthesis and destruction in corn seedlings under salinity environment and synthetic growth regulators impact. Reports of the NAS of Ukraine, 2007; 3: 191-195. (In Ukrainian).

14. Deinlein U., Stephan A. B., Horie T. et al. Plant salt-tolerance mechanisms Trends in Plant Science, 2014; 19(6): 371-379.

15. Derkach I.V., Romanyuk N.D. Effect of $\mathrm{NaCl}$ salinity on growth and pigment system of Fagopyrum esculentum Moench. and Vicia faba L. plants. J. of Karazin Kharkiv Nat. Univ., Ser. Biol, 2015; 25: 308-319. (In Ukrainian).

16. Drop B., Webber-Birungi M., Yadav S.K.N. et al. Light-harvesting complex II and its supramolecular organization in Chlamydomonas reinhardtii. Biochimica et Biophysica Acta, 2014; 1837(1): 63-72.

17. Ehab A. I. Seed priming to alleviate salinity stress in germinating seeds. J. Plant Physiol, 2016; 192(15): 38-46.

18. El-Naim A.M., Mohammed K.E., Enab I.A. et al. Impact of salinity on seed germination and early seedling growth of three sorghum (Sorghum bicolor L.) cultivars. Sci. Technol, 2012; 2(2): 16-20.

19. Ermakov A. I. Methods of Biochemical Analysis of Plants. L.: Kolos, 1972; 456 p.

20. FAO 2015 Social protection and agriculture: breaking the cycle of rural poverty: The State of Food and Agriculture, Rome 13, October, 2015, 150 p. (http://www.fao.org/3/a-i4910e.pdf)

21. Ghezal N., Rinez I., Sbai H. et al. Improvement of Pisum sativum salt stress tolerance by biopriming their seeds using Typha angustifolia leaves aqueous extract. South Afr. J. of Botany, 2016; 105: 240-250.

22. Heidari M., Sarani S. Growth, biochemical components and ion content of Chamomile (M. chamomilla L.) under salinity stress and iron deficiency. J. of the Saudi Soc. of Agricult. Sci, 2012; 11(1): 37-42.

23. Isayenkov S.V. Physiological and molecular aspects of salt stress in plants. Cytol. Genet, 2012; 46(5): 302-318.

24. Kabuzenko S. M. Zhyzhyna M.N., Ponomarenko S.P. et al. Synthetic growth regulators ivin and BAP influence on water exchange values in corn and barely germs in salt soil. Physiol. and Biochem. of Cult. Plants, 2009; 41(2): 146-153. (In Ukrainian).

25. Kalinina N.O., Kabuzenko S.M. Method for corn biomass increasing on salinized soils. Patent \# 36600, 16.04.2001 Ukrainian Patents Database http://uapatents.com/2-36600-sposibpidvishhennya-nakopichennya-biomasi-kukurudzi-na-zasolenikh-gruntakh.html

26. Kamel M., Hammad $\mathrm{S}$. Is the soil $\mathrm{K} / \mathrm{Na}$ ratio the first defense line against salinity? European J. of Biological Research, 2015; 5: 42-51.

27. Karajol K., Naik G.R. Seed germination rate as a phenotypical marker for the selectionof $\mathrm{NaCl}$ tolerant cultivars in pigeon pea (Cajanus cajan L.; MILLSP.). World J. Sci. Technol, 2011; 1(2): 1-8. 
28. Kaya M.D., Okçu G., Atak M. et al. Seed treatments to overcome salt and drought stress during germination in sunflower (Helianthus annuus L.). Europ. J. Agronomy, 2006; 24: 291 295.

29. Kolesnikov M.O. Tocopherol influence on pea (Pisum sativum L.) germination and formation of its biological yields. Agrobiology, 2013; 11(104): 115-119.

30. Leonforte A., Forster J., Redden R. et al. Sources of high tolerance to salinity in pea (Pisum sativum L.) Euphytica, 2013; 189(2): 203-216.

31. Lutsenko E.K., Marushko Ye.A., Kononenko T.G. Influence of fusicoccin on early growth of sorgo under high $\mathrm{NaCl}$ concentrations. Plant Physiology, 2005; 52(3): 378-383. (In Russian).

32. Mani F. Effect of salt stress on physiological attributes of pea (Pisum sativum). IJASR, 2015; 5(1): 29-42.

33. Mazher A., El-Quesni E., Farahat M.M. Responses of ornamental and woody trees to salinity. World J. Agric. Sci, 2007; 3(3): 386-395.

34. Meloni D.A., Oliva A.A., Martinez Z.A. et al. Photosynthesis and activity of superoxide dismutase, peroxidase and glutathione reductase in cotton under salt stress. Environ. Exp. Bot, 2003; 49: 69-76.

35. Merkushyna A.S. Physiologically-biochemical basis of gibberellins influence on pea plants and phytophags. Kyiv: Silgosposvita, 1994. 57-60 p. (in Ukrainian).

36. Munns R. Comparative Physiology of Salt and Water Stress. Plant Cell Environ, 2002; 25(2): 239-250.

37. Munns R., Tester M. Mechanisms of Salinity Tolerance. Ann. Rev. Plant. Biol, 2008; 59: 651-681.

38. Musienko M.M., Parshykova T.V., Slavnyy P.S. Spectrophoto-metrical methods in plant physiology and ecology. Kyiv: Phytosociocenter, 2001. 200 p.

39. Noreen S., Ashraf M., Hussain M. Exogenous application of salicylic acid enhances antioxidative capacity in salt stressed sunflower. Pak. J. Bot, 2009; 41(1): 473-479.

40. Parida .A.K; Das.A.B, Mittra.B. Effects of salt on growth ion accumulationphotosynthesis and leaf anatomy of the mangrove Brugulera paviflora. Trees: Structure and Function, 2004; 18: $167-174$.

41. Patanè C., Cavallaro V., Cosentino S.L. Germination and radicle growth in unprimed and primed seeds of sweet sorghum as affected by reduced water potential in $\mathrm{NaCl}$ at different temperatures. Industrial Crops and Products, 2009; 30(1): 1-8.

42. Pjurko O.Ye., Kazakova S.M. Some aspects of salt of Pryazovja plants. Materials of USB: Kharkiv, 25-27 September, 2001. Kharkiv: B.V., 2001: 319-320. (In Ukrainian).

43. Pjurko O.Ye., Musiyenko M.M., Kazakov Ye.O. et al. Basics of plant salt tolerance and methods of its investigation. Visnyk Zaporizhzhia State Univ. Biology Sci, 2001; 1: 204-208. (In Ukrainian).

44. Plant Biostimulants. Kyiv: Agrobiothech, 2013-2014: 29 p. (In Russian).

45. Ponomarenko S.P. Growth Regulators. Environmental aspects of application. Plant Protection J, 1999; 12: P. 15. (In Ukrainian).

46. Prado F.E., Boero C., Gallardo S. Efect of $\mathrm{NaCl}$ on germination, growth and soluble sugars content Chenopodium quinoa Willd. Seeds Bot. Bull. Acad. Sin, 2000; 41: 27-34.

47. Ribchenko Zh. I., Palladina T.A. The action of adaptogenic preparations on vacuolar proton pumps activity in corn root cells under salt stress conditions. Ukr. Biochem. J, 2012; 84(3): 88-93.

48. Rodriguez-Navarno A. Potassium Transport in Fungi and Plants Biochem. Biophys. Acta, 2000; 1469: 1-30.

49. Roy S. J., Negra S., Tester M. Salt resistant crop plants. Current Opinion in Biotechnology, 2014; 26: 115-124.

50. Saida $C$., Hadjar S., Belgat $H$. et al. Interactive effects of potassium and sodium on the growth and nodulating capacity of pea (Pisum sativum L.) var: Merveilede Kelvedon under salt stress. Agriculture and Biology J. of North America, 2015; 6(1): 34-46.

ISSN 1996-4536 (print) • ISSN 2311-0783 (on-line) • Біологічні Студії / Studia Biologica • 2016 • Том 10/№3-4 • С. 107-118 
51. Salt Stress Signaling Pathways: Specificity and Cross Talk in Book: Managing salinity tolerance in plants: molecular and genomic perspectives. Chapt: Salt stress signalling pathways: specificity and crosstalk., CRC Press, (Ed.): Wani S.H., Hossain M.A., 2015: 51-78.

52. Serrano R., Mulet J.M. A Glimpse of the Mechanism of lon Homeostasis during Salt Stress. J. Exp. Bot, 1999; 50: 1023-1036.

53. Shabala S, Cuin TA Potassium transport and plant salt tolerance. Physiol. Plant, 2008; 133(4): 651-69.

54. Shevchenko A.O., Anishyn L.A. Reserves of wheat growing. Bio-promoters of new era. Plant Protection J, 1997; 10: 21. (In Ukrainian).

55. Stepien P., Klobus G. Water relations and photosynthesis in Cucumis sativus L. leaves under salt stress. Biol. Plantarum, 2006; 50(4): 610-616.

56. Taffouo V.D., Wamba O.F., Yombi E. et al. Growth, yield, water status and ionic distribution response of three bambara groundnut (Vigna subterranean (L.) verdc.) landraces grown under saline condition. Int. J. Bot, 2010; 6(1): 53-58.

57. Tavakkoli E., Paull J., Rengasamy P. et al. Comparing genotypic variation in faba bean (Vicia faba L.) in response to salinity in hydroponic and field experiments. Field Crops Research, 2012; 127: 99-108.

58. Tester N., Davenport R. $\mathrm{Na}^{+}$tolerance and $\mathrm{Na}^{+}$transport in higher plants. Annals of Botany, 2003; 91: 1-25.

59. Tort N., Turkyilmaz B. A physiological investigation on the mechanisms of salinity tolerance in some barley culture forms. J. F. S, 2004; 27: 1-16.

60. Turan M.A., Kalkat V., Taban S. Salinity-induced stomatal resistance, proline, chlorophyll and Ion concentrations of bean. Int. J. Agric. Res, 2007; 2(5): 483-488.

61. Tyschenko O.D., Tyschenko A.V.,Chernychenko M.I. Sat tolerance of alfalfa and the ways of its improvement. Irrigated Agricult, 2013; 59: 105-108. (In Ukrainian).

62. Waheed A., Hamid F.S., Gul H. et al. Effect of sowing date in the performance of pea plant (Pisum sativum) under agro climatic condition of Mansehra. Moroccan J. of Chemistry, 2015; 3(4): 713-722.

63. www.agrobiotech.com.ua

64. Zhu J.K. Regulation of ion homeostasis under salt stress. Curr. Opin. Plant Biol, 2003; 6(5): 441-445.

65. Zhu J.K., Hasegawa P.M. Molecular Aspects of Osmotic Stress in Plants. Crit. Rev. Plant. Sci, 1997; 16: 253-277.

\title{
ВПЛИВ ПЕРЕДОБРОБКИ НАСІННЯ РЕГУЛЯТОРОМ РОСТУ БІОЛАН HA СОЛЕСТІЙКІСТЬ PISUM SATIVUM L.
}

\author{
М. В. Дмитрук, Н. В. Василів, І. В. Деркач, І. М. Микієвич, Н. Д. Романюк \\ Львівський національний університет імені Івана Франка \\ вул. Грушевського, 4, Львів 79005, Україна \\ *e-mail: biofr@franko.Inu.edu
}

Регулятор росту Біолан (Агробіотех, Київ) під час застосування для передобробки насіння в лабораторних умовах ґрунтової культури позитивно впливав на фізіологічні реакції Pisum sativum L. (сорт Альфа) за наявності 0 (контроль), 2 і 4\% $\mathrm{NaCl}$. $\mathrm{NaCl}$ затримував у часі поглинання води насінням, яке проростало, ріст ембріональних осьових органів, знижував енергію проростання і пригнічував початкові етапи росту (акумулювання сирої та сухої речовини), вміст хлорофілів $a, b$ і каротиноїдів. За дії $2 \% \mathrm{NaCl}$ порушувався гомеостаз $\mathrm{Na}^{+}, \mathrm{Ca}^{2+}$ і $\mathrm{K}^{+}$; вміст $\mathrm{Ca}$ і співвідношення K / Na різко знижувалися. Біолан у розведенні 1:105 (6 год) стимулював 
поглинання води і проростання насіння. Виявлено зміни співвідношення Хл $a$ / $b$ у листках рослин залежно від наявності солі в середовищі. Обробка насіння Біоланом частково відновлювала співвідношення K / Na і незначно знімала загальний інгібуючий ефект дії солі, що дає підстави для можливого застосування регулятора з метою підвищення солестійкості гороху в польових умовах.

Ключові слова: Pisum sativum L., регулятор росту рослин, передобробка насіння, Біолан, $\mathrm{NaCl}$, солестійкість.

\section{ВЛИЯНИЕ ОБРАБОТКИ СЕМЯН РЕГУЛЯТОРОМ РОСТА БИОЛАН НА СОЛЕСТОЙКОСТЬ PISUM SATIVUM L.}

\section{М. В. Дмитрук, Н. В. Васылия, И. В. Деркач, И. М. Мыкиевич, Н. Д. Романюк* \\ Львовский национальный университет имени Ивана Франко ул. Грушевского, 4, Львов 79005, Украина, *e-mail: n_romanyuk@franko.Inu.edu}

Регулятор роста Биолан (Агробиотех, Киев) при применении для предобработки семян в лабораторных условиях положительно влиял на фризиологические и биохимические реакции Pisum sativum L. (сорт Альфа) в присутствии 0 (контроль), 2 и 4\% $\mathrm{NaCl}$. NaCl задерживал во времени поглощение воды прорастающими семенами, рост эмбриональных осевых органов, снижал энергию прорастания и начальные этапы роста (аккумуляцию сырого и сухого вещества), содержание хлорофиллов $a, b$ и каротиноидов. Гомеостаз $\mathrm{Na}^{+}, \mathrm{Ca}^{2+}$ и $\mathrm{K}^{+}$под влиянием $2 \% \mathrm{NaCl}$ смещался, содержание Са и соотношение K / Na резко снижалось. Биолан в разведении $1: 10^{5}$ (6 ч) стимулировал процесс поглощения воды и прорастание семян. Наблюдали изменение соотношения Хл $a$ / b в листьях растений в зависимости от присутствия соли в среде. Обработка семян Биоланом частично восстанавливала соотношение K / Na и незначительно снимала общий ингибиторный эффект действия засоления, что дает основания для возможного применения регулятора с целью повышения солестойкости растений гороха в полевых условиях.

Ключевые слова: Pisum sativum L., регулятор роста растений, обработка семян, Биолан, $\mathrm{NaCl}$, солестойкость.

Одержано: 03.11.2016

ISSN 1996-4536 (print) • ISSN 2311-0783 (on-line) • Біологічні Студії / Studia Biologica • 2016 • Том 10/№3-4 • С. 107-118 